\title{
Diagnostic Algorithm for the Rapid and Cost- Effective Detection of Clostridioides difficile Infection: Comparison between C. DIFF QUIK CHEK COMPLETE and VIDAS GDH \& Toxin Assay
}

\author{
Soo Jin Yoo ${ }^{1}$ and Dong Hee Whang ${ }^{2}$ \\ ${ }^{1}$ Department of Laboratory Medicine, Sanggye Paik Hospital, Inje University College of Medicine; ${ }^{2}$ Department of Laboratory \\ Medicine, Seoul Paik Hospital, Inje University College of Medicine, Seoul, Korea
}

\section{Corresponding author:}

Dong Hee Whang

Department of Laboratory Medicine,

Seoul Paik Hospital, Inje University

College of Medicine, 9 Mareunnae-ro, Jung-gu, Seoul 04551, Korea

Tel +82-2-2270-0152

Fax +82-2-2270-0148

E-mail dhwhang@paik.ac.kr

Received: May 26, 2020

Revised: July 3, 2020

Accepted: July 17, 2020
This is an Open Access article distributed under the terms of the Creative Commons Attribution Non-Commercial License (http://creativecommons.org/licenses/ by-nc/4.0) which permits unrestricted non-commercial use, distribution, and reproduction in any medium, provided the original work is properly cited.
Background: We evaluated the analytical performance and cost-effectiveness of lateral flow immunoassays (LFIAs) in detecting Clostridioides difficile glutamate dehydrogenase (GDH) antigen and toxin A/B, followed by a rapid nucleic acid amplification test (NAAT).

Methods: A total of 341 unformed stools were tested using a two-step algorithmic approach with C. DIFF QUIK CHEK COMPLETE (QCC) LFIA (TechLab, USA), followed by Xpert $C$. difficile NAAT (Xpert). The performance of the QCC assay was compared with that of the VIDAS $C$. difficile GDH and toxin A/B assay (bioMérieux, France), an enzyme-linked fluorescence immunoassay. The clinical performance and cost-effectiveness of the diagnostic algorithms using the QCC or VIDAS assays were compared to the results obtained using the Xpert assay alone.

Results: For GDH and toxin detection, the QCC and VIDAS assays demonstrated an almost perfect agreement, with no significant difference in sensitivity (QCC-GDH, 90.5\%; VIDAS-GDH, 91.9\%; QCC-toxin, 51.4\%; VIDAStoxin, 55.4\%) and specificity (QCC-GDH, 92.9\%; VIDAS-GDH, 89.1\%; QCC-toxin, $100 \%$; VIDAS-toxin, 99.6\%), compared to the Xpert. The algorithmic approach (GDH and toxin plus Xpert) increased the sensitivity (QCC, 93.2\%; VIDAS, 94.6\%) and specificity (QCC, 100\%; VIDAS, 99.6\%). The algorithmic approach reduced the cost compared to the Xpert alone, and the turnaround time of the QCC was shorter than that of the VIDAS assay.

Conclusions: Simultaneous detection of GDH and toxin A/B, using QCC or VIDAS assays showed comparable sensitivity and specificity when followed by the Xpert assay. The QCC assay is preferable in turnaround time and cost, which are important considerations for laboratories handling smaller number of samples.

(Lab Med Qual Assur 2020;42:130-139)

Key Words Clostridioides difficile infection, Immunoassay, Algorithms 


\section{INTRODUCTION}

Clostridioides difficile is a gram-positive, spore-forming, anaerobic bacillus, which produces toxins that attack the lining of the intestine [1]. C. difficile infection (CDI) is a major nosocomial disease, with variable clinical symptoms ranging from asymptomatic colonization and diarrhea to life-threatening inflammation, such as pseudomembranous colitis and toxic megacolon [1,2]. In recent years, CDI has become more frequent, severe, and difficult to treat in high-income countries [3,4]. In Korea, the incidence of CDI has also been trending higher, although diagnostic methods used yield variable results [5-7].

The clinical symptoms of CDI can be similar to those of diarrhea, caused by a change in diet, antibiotic treatment, or infection with other pathogens such as Salmonella. Therefore, accurate and rapid laboratory diagnosis of $C D I$ is essential to treat patients properly and establish appropriate nosocomial infection control measures.

Toxigenic $C$. difficile culture (TC) and cell culture cytotoxin neutralization assay (CCNA) have been regarded as the gold standard methods for diagnosing CDI; however, they are labor-intensive and time-consuming, limiting their use in clinical laboratories [8]. Nucleic acid amplification testing (NAAT)-based assays detect toxin genes and represent a confirmatory method with high sensitivity and specificity that can replace the cumbersome TC [9-11]. Rapid NAATs using real-time polymerase chain reaction (PCR) techniques with short turnaround time (TAT) have recently become more widely available. However, their relatively high cost limits their universal use. Glutamate dehydrogenase (GDH), a common antigen present in the C. difficile cell wall, is a sensitive marker for $C$. difficile detection and is recommended as a high-sensitivity screening tool $[12,13]$. Immunoassays for GDH antigens detect non-toxigenic and toxigenic $C$. difficile, as well as certain other clostridial species. Therefore, they should be used in combination with a C. difficile toxin assay [14]. Immunoassays for toxin detection are widely available but less sensitive. To compensate for the advantages and disadvantages of these various methods, multistep algorithms including GDH and/or toxin immunoassays along with NAATs are recommended and used in many laboratories [15-18].

Lateral flow immunoassays (LFIAs) are rapid and simple tests but have limitations such as low sensitivity and subjective interpretation. Nonetheless, LFIAs are portable, stable, cost-effective, and easy to use. The simplicity of commercially available LFIA-based tests for initial assessment of CDI has utility in clinics that do not have immediate access to clinical instruments and NAAT technologies. LFIAs for CDI diagnosis are even being multiplexed to detect GDH and toxins on the same strip.

Some reports have evaluated LFIAs, rapid NAATs, and algorithmic approaches utilizing these assays [19-21]. However, the clinical performance, costs, and TAT of an algorithmic approach using an LFIA and a rapid NAAT have not been evaluated in Korea.

This study aimed to determine the diagnostic performance and clinical efficiency of LFIAs for CDI diagnosis by comparing the C. DIFF QUIK CHEK COMPLETE (QCC; TechLab, Blacksburg, VA, USA) assay, which detects GDH and toxin $A / B$ on the same cassette, to the widely used VIDAS C. difficile GDH and toxin A/B assay (bioMérieux, Marcy-L'Etoile, France) based on a rapid NAAT. We also evaluated the diagnostic efficiency of multistep approaches using GDH and toxin assays followed by a rapid NAAT.

\section{MATERIALS AND METHODS}

\section{Clinical samples}

This study involved unformed stool specimens submitted to the department of laboratory medicine, Inje University Seoul Paik Hospital in Korea for detection of $C$. difficile between June 2016 and August 2017. Duplicate samples and samples from patients being treated for CDI were excluded. During the study period, a total of 341 stool specimens were collected from adult patients (age $>18$ years). Rapid NAAT tests were performed as a routine diagnostic procedure. Then the remaining samples were tested for the presence of the GDH antigen and toxin A/B using two sets of immunological tests; the VIDAS C. difficile GDH (VIDAS GDH; bioMérieux) and VIDAS C. difficile toxin 
A/B (VIDAS CDAB; bioMérieux) assays (performed in a separate cassette, at the same time), and the C. DIFF QUIK CHEK COMPLETE (QCC; TechLab) assay. The samples were tested on the day of collection, or otherwise stored at $4^{\circ} \mathrm{C}$ and tested within 24 hours of collection.

This in vitro study protocol was approved by the Institutional Review Board of Inje University Seoul Paik Hospital (IIT2-2016-103). The data were analyzed anonymously, and the enrolled patients were exempted from providing written informed consent.

\section{Xpert $C$. difficile assay}

The Xpert C. difficile assay (Xpert; Cepheid, Sunnyvale, CA, USA) is a rapid, fully automated, multiplex real-time PCR-based assay that detects the toxin $B$ gene $(t c d B)$, the binary toxin genes ( $c d t A$ and $c d t B$ ), and a point mutation associated with PCR ribotype 027 using the GeneXpert platform (Cepheid). The assay was performed according to the manufacturer's instructions. In the case where the test results stated "invalid," "error," or "no results", the test was repeated within 3 hours according to the manufacturer's instructions.

\section{C. DIFF QUIK CHEK COMPLETE assay}

The QCC assay is a lateral flow membrane enzyme immunoassay (EIA) that detects GDH antigen and toxin $\mathrm{A} /$ $B$ in one cassette. This cassette has a central dotted line for the control as well as two separate test lines, with one for the GDH antigen (QCC GDH) test and the other for the toxin $A / B$ (QCC toxin) test. The QCC assay was performed according to the manufacturer's instructions. Briefly, 25 $\mu \mathrm{L}$ of stool specimen was added to a tube containing the diluents and conjugate, and the mixture was transferred to the sample well of the device. After incubation for 15 minutes at room temperature, the wash buffer and substrate were added to the reaction window. The results were read 10 minutes later. The GDH antigen and toxin assays were reported as positive if a corresponding visible band was seen on the device display window.

\section{VIDAS $C$. difficile GDH and VIDAS $C$. difficile toxin A/B}

Each stool specimen was examined for both the GDH antigen and toxins using the VIDAS GDH and VIDAS CDAB assays, in a separate cassette, at the same time. The assays involve a two-step sandwich immunoassay using the enzyme-linked fluorescence immunoassay technique. Aliquots of liquid stools were added to a dedicated diluent, and after centrifugation, the supernatant was used for testing and the results were interpreted with optical density (OD) cutoff using the spectrophotometric dual-wavelength 450/630 $\mathrm{nm}$ according to the manufacturer's instructions. Samples from the VIDAS GDH assay were defined as negative with an $O D<0.10$ and positive with an $O D \geq 0.10$. For the VIDAS CDAB, a fluorescence intensity of $<0.13$ indicated a negative test, $\geq 0.13$ to $<0.37$ an equivocal test, and $\geq 0.37$ a positive test. An equivocal result was considered negative for the performance calculations in this study. The on-board analysis time for one sample was 50 minutes in the VIDAS GDH assay and 75 minutes in the VIDAS CDAB assay.

\section{Diagnostic algorithms}

We utilized a two-step diagnostic algorithm to identify toxigenic C. difficile-positive samples (Fig. 1). First, all the specimens were screened using two separate immunologic methods (QCC and VIDAS) for detecting both $\mathrm{GDH}$ and toxin $\mathrm{A} / \mathrm{B}$. If a sample showed discordant results for GDH and toxins in either method, the Xpert assay was utilized to determine the result. We compared the results, cost, and assay times of the following algorithms; the Xpert assay only, the QCC plus Xpert assays, and the VIDAS GDH and toxin plus Xpert assays. The cost per sample included reagent costs only; other costs, such as labor or quality control, were not included. The assay time was estimated by processing six samples, which is the maximum number of samples that can be tested for GDH and toxins at a time on the mini VIDAS equipment (bioMérieux). The assay time included analysis time only and therefore excluded the pre-analysis, preparation, and post-analysis phases. The VIDAS assay time was calculated from samples when the GDH and toxin $A / B$ assays were 
performed concurrently in separate racks. The average assay time was calculated using the actual time required for each sample when the algorithmic approach was applied.

\section{Statistical analysis}

Based on the results of the Xpert assay, the sensitivity and specificity of each assay and algorithm were calculated and their differences were tested using the McNemar test. Cohen's kappa index was calculated for agreement between the assays (agreement: $<0.2$, none; 0.21-0.39, minimal; 0.40-0.59, weak; 0.60-0.79, moderate; 0.80-0.90, strong; >0.90, almost perfect) [22]. Statistical analysis was performed using MedCalc statistical software ver. 18.6 (MedCalc Software, Mariakerke, Belgium). $P$-values less than 0.05 were considered statistically significant.

\section{RESULTS}

\section{Agreement and performance of each immunoassay based on Xpert confirmation}

Among the 341 stool samples studied, 74 samples (21.7\%) were positive for $C$. difficile toxin genes using the
Xpert system. For GDH antigen detection, the QCC GDH and VIDAS GDH assays showed almost perfect agreement (kappa $=0.918$ ) (Table 1). Eleven samples showed discordant results and all of them were negative using the QCC GDH assay and positive using the VIDAS GDH assay, and only one of them $(1 / 11,9.1 \%)$ was confirmed to be positive using the Xpert assay. Using confirmation by the Xpert assay, the QCC and VIDAS GDH assays showed comparable diagnostic sensitivity and specificity

Table 1. Comparison of the results of the QCC and VIDAS assays for the detection of Clostridioides difficile GDH and toxin A/B

\begin{tabular}{|c|c|c|c|c|c|}
\hline \multirow{2}{*}{ Target } & \multirow{2}{*}{ Test } & \multirow{2}{*}{ Results } & \multicolumn{2}{|c|}{$\begin{array}{l}\text { No. of } \\
\text { samples } \\
\text { (VIDAS) }\end{array}$} & \multirow{2}{*}{$\begin{array}{c}\text { Kappa value } \\
(95 \% \mathrm{CI})\end{array}$} \\
\hline & & & $\begin{array}{l}\text { Posi- } \\
\text { tive }\end{array}$ & $\begin{array}{l}\text { Nega- } \\
\text { tive }\end{array}$ & \\
\hline \multirow[t]{2}{*}{ GDH } & QCC & Positive & 86 & 0 & $0.918(0.87-0.965)$ \\
\hline & & Negative & 11 & 244 & \\
\hline \multirow[t]{2}{*}{ Toxin A/B } & QCC & Positive & 37 & 1 & $0.956(0.907-1.0)$ \\
\hline & & Negative & 5 & 298 & \\
\hline
\end{tabular}

Abbreviations: QCC, C. DIFF QUIK CHEK COMPLETE; VIDAS, VIDAS C. difficile GDH and VIDAS $C$. difficile toxin A/B assay; GDH, glutamate dehydrogenase; $\mathrm{Cl}$, confidence interval.
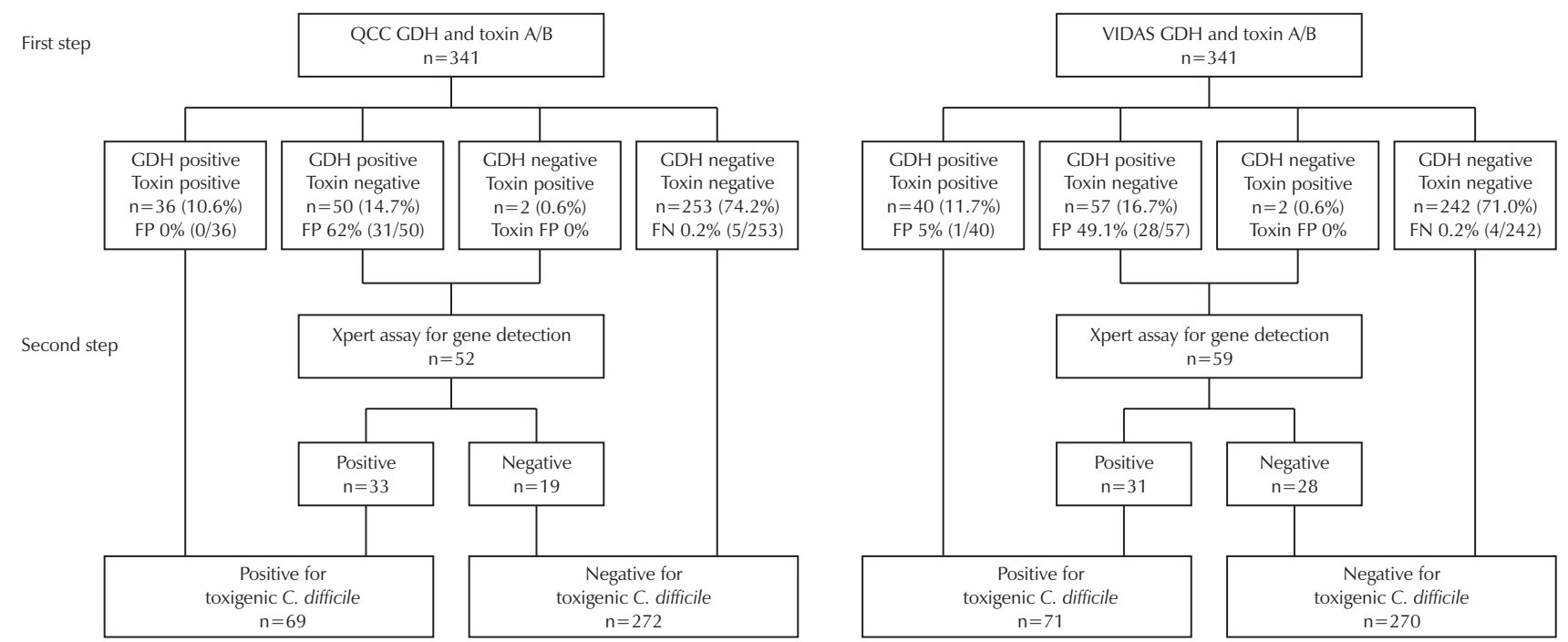

Fig. 1. Two-step diagnostic algorithms and the distributions of samples for which diagnosis was established in each step for the detection of toxigenic Clostridioides difficile infection. Combined two-step algorithms in which the initial screening was performed with QCC (GDH and toxin) and followed by the Xpert assay in discordant samples (left) and combined algorithm with VIDAS GDH and VIDAS toxin A/ B followed by Xpert assay (right). Abbreviations: QCC, C DIFF QUIK CHEK COMPLETE; GDH, glutamate dehydrogenase; VIDAS, VIDAS C. difficile GDH and VIDAS C. difficile toxin A/B assay; FP, false positive; FN, false negative; Xpert assay, Xpert C. difficile RT-PCR assay. 
Table 2. Sensitivities and specificities of the Clostridioides difficile GDH and toxin immunoassays and algorithmic approaches based on the Xpert assay

\begin{tabular}{|c|c|c|c|c|c|c|}
\hline \multirow[b]{2}{*}{ Assays } & \multirow[b]{2}{*}{ Result } & \multicolumn{2}{|c|}{ Xpert assay } & \multirow[b]{2}{*}{ Sensitivity $\%(95 \% \mathrm{CI})$} & \multirow[b]{2}{*}{ Specificity\% $(95 \% \mathrm{CI})$} & \multirow[b]{2}{*}{ Kappa $(95 \%$ Cl) } \\
\hline & & $\begin{array}{l}\text { Positive } \\
(\mathrm{N}=74)\end{array}$ & $\begin{array}{c}\text { Negative } \\
(\mathrm{N}=267)\end{array}$ & & & \\
\hline \multirow[t]{2}{*}{ QCC GDH } & Positive & 67 & 19 & $90.5(81.5-96.1)$ & $92.9(89.1-95.7)$ & $0.788(0.711-0.866)$ \\
\hline & Negative & 7 & 248 & & & \\
\hline \multirow[t]{2}{*}{ VIDAS GDH } & Positive & 68 & 29 & $91.9(83.2-97.0)$ & $89.1(84.8-92.6)$ & $0.728(0.645-0.812)$ \\
\hline & Negative & 6 & 238 & & & \\
\hline \multirow[t]{2}{*}{ QCC toxin } & Positive & 38 & 0 & $51.4(39.4-63.1)$ & $100.0(98.6-100.0)$ & $0.623(0.515-0.731)$ \\
\hline & Negative & 36 & 267 & & & \\
\hline \multirow[t]{2}{*}{ VIDAS toxin } & Positive & 41 & 1 & $55.4(43.4-67.0)$ & 99.6 (97.9-100.0) & $0.652(0.548-0.757)$ \\
\hline & Negative & 33 & 266 & & & \\
\hline \multirow{2}{*}{$\begin{array}{l}\text { QCC GDH \& toxin } \\
\text { plus Xpert }\end{array}$} & Positive & 69 & 0 & 93.2 (84.9-97.8) & $100.0(98.6-100.0)$ & $0.956(0.917-0.994)$ \\
\hline & Negative & 5 & 267 & & & \\
\hline \multirow[t]{2}{*}{$\begin{array}{l}\text { VIDAS GDH \& toxin } \\
\text { plus Xpert }\end{array}$} & Positive & 70 & 1 & $94.6(86.7-98.5)$ & 99.6 (97.9-100.0) & $0.956(0.918-0.994)$ \\
\hline & Negative & 4 & 266 & & & \\
\hline
\end{tabular}

Abbreviations: GDH, glutamate dehydrogenase; Xpert assay, Xpert C. difficile RT-PCR assay; Cl, confidence interval; QCC, C. DIFF QUIK CHEK COMPLETE; VIDAS, VIDAS $C$. difficile GDH and VIDAS $C$. difficile toxin A/B assay.

(approximately 90\%) (Table 2).

For toxin $\mathrm{A} / \mathrm{B}$ detection, the QCC toxin and VIDAS CDAB assays showed almost perfect agreement (kappa $=0.956$ ) (Table 1). Discrepant results between the QCC toxin and VIDAS CDAB assays were observed in six samples. One of them was positive using the QCC toxin assay and negative using the VIDAS CDAB assay and was confirmed to be positive using the Xpert assay. Five discrepant samples were negative using the QCC toxin assay and positive using the VIDAS CDAB assay, and four of them were confirmed to be positive using the Xpert assay. Using confirmation by the Xpert assay, the QCC toxin and VIDAS CDAB assays showed low sensitivities (51.4\% and 55.4\%, respectively) (Table 2). Approximately half of the Xpertpositive samples were positive using both the GDH and toxin assays; 36/74 (51.4\%) using the QCC assay and 39/74 (55.4\%) using the VIDAS assay (Table 2).

\section{Diagnostic performance of the two-step algorithms}

We simulated the two-step testing algorithm by em- ploying QCC or VIDAS GDH and toxin assays as a first-line test, followed by the Xpert assay (Fig. 1). Compared with the Xpert system alone, the two-step algorithms increased sensitivity (93.2\% using the QCC assays and $94.6 \%$ using the VIDAS assays) and specificity (100\% using the QC assays and $99.6 \%$ using the VIDAS assays), with an almost perfect agreement (kappa $=0.956$ for both the QCC and VIDAS assays) (Table 2).

Fig. 1 shows the distribution of samples in each step of the algorithms. In the first step using the GDH and toxin immunoassays, 289 samples (84.8\%) using the QCC assays, and 282 samples (82.7\%) using the VIDAS assays were GDH-positive/toxin-positive or GDH-negative/toxinnegative, meaning no further test was required for the diagnosis of CDI. In the two-step algorithm using the QCC GDH and toxin assays, 336 samples (98.5\%) were correctly classified based on confirmation via the Xpert assay. Five samples (1.5\%) with Xpert-positive results were regarded as negative based on the QCC GDH-negative/toxinnegative results. Using the VIDAS GDH and toxin assays, 336 samples (98.5\%) were correctly classified in the two- 
Table 3. Comparison of the diagnostic rate, cost, and turnaround time for the one-step Xpert assay and two-step algorithmic approach using QCC and VIDAS GDH and toxin followed by the Xpert assay

\begin{tabular}{|c|c|c|c|c|c|c|}
\hline \multirow{2}{*}{ Test methods } & \multicolumn{2}{|c|}{ Samples reported $(\mathrm{N}, \%)$} & \multicolumn{2}{|c|}{ Cost/sample (US\$) } & \multicolumn{2}{|c|}{ Assay time/sample (min) } \\
\hline & QCC & VIDAS & QCC & VIDAS & QCC & VIDAS \\
\hline \multicolumn{7}{|c|}{ GDH \& toxin plus Xpert } \\
\hline 1-Step & $289(84.8)$ & $282(82.7)$ & 8 & 10 & 40 & 85 \\
\hline 2-Step & $52(15.2)$ & $59(17.3)$ & $8+47$ & $10+47$ & $40+50$ & $85+50$ \\
\hline Average & - & - & 15.2 & 18.1 & 47.6 & 93.7 \\
\hline Xpert only & \multicolumn{2}{|c|}{$341(100.0)$} & \multicolumn{2}{|c|}{47} & \multicolumn{2}{|c|}{50} \\
\hline
\end{tabular}

Abbreviations: Xpert assay, Xpert C. difficile RT-PCR assay; QCC, C. DIFF QUIK CHEK COMPLETE; VIDAS, VIDAS C. difficile GDH and VIDAS C. difficile toxin A/B assay; GDH, glutamate dehydrogenase.

step algorithm, while four VIDAS GDH-negative/toxinnegative samples were positive using the Xpert assay, and one VIDAS GDH-positive/toxin-positive sample was negative using the Xpert assay. Among a total of 50 QCC GDH-positive/toxin-negative samples, 31 were positive using the Xpert assay, suggesting a $62 \%$ false negativity based on the QCC toxin assay. Among a total of 57 VIDAS GDH-positive/toxin-negative samples, 28 were positive using the Xpert assay, suggesting a $49.1 \%$ false negativity based on the VIDAS toxin assay (Fig. 1). Two Xpert-positive samples were GDH-negative/toxin-positive using both the QCC and VIDAS assays, suggesting false negativity of the GDH assay.

\section{Comparison of assay time and costs}

The algorithms were compared based upon the distribution of samples, estimated average material cost per sample, and the time-to-result for each assay (Table 3). The Xpert assay reported the result of each sample within 50 minutes, including 10 minutes of preparation time at $\$ 47$ per sample. Using the QCC assay for initial testing reported the results for $84.8 \%$ of the samples within 40 minutes at $\$ 8$ per sample. The VIDAS GDH and toxin assay reported the results of $82.7 \%$ of the samples within 85 minutes at $\$ 10$ per sample. When using either assay for initial testing, with the Xpert assay for secondary testing, the QCC/Xpert combination took 90 minutes at $\$ 55$ per sample and the VIDAS/Xpert combination took 135 minutes at $\$ 57$ per sample.

Based on the distribution of samples used in this study, the average cost per sample using the two-step algorithm was estimated as $\$ 15.20$ using the QCC assay and $\$ 18.10$ using the VIDAS assay as the first-line assay. Both of these represent a lower cost than using the Xpert system alone (\$47). The average assay time for the two-step algorithm was 47.6 minutes using the QCC assay, and 93.7 minutes using the VIDAS platforms, whereas 50 minutes using the Xpert system alone.

\section{DISCUSSION}

The best practice for laboratory diagnosis of CDI remains unresolved even though many sensitive, specific, and rapid commercial methods have been introduced. A recent meta-analysis in Korea showed that the widelyused GDH EIA and NAATs are highly sensitive and specific (pooled sensitivities and specificities above 90\%) [23]. However, they do not detect free toxins and therefore cannot differentiate between colonization and disease $[24,25]$. Rapid NAAT, as a single diagnostic method, could lead to decreases in the length of stay (approximately 2 days), days on empiric CDI treatment and isolation, and associated costs $[17,26]$. However, the change in CDI diagnosis from EIA to NAAT alone increased CDI incidence (14\%-53\%) and a decrease in the CDI complication rate, suggesting overdiagnosis, overtreatment, and larger economic burdens [26-29]. EIAs for C. difficile toxins showed higher specificities (pooled sensitivity of $57.9 \%$ and specificity of $97.0 \%$ ) and improved positive predictive values (PPVs). Considering that CDI prevalence 
is $5 \%-10 \%$ in an endemic setting, the pooled PPVs at $5 \%$ CDI prevalence were $47 \%-50 \%$ for GDH EIA, 50\%-60\% for toxin A/B EIA, and $53 \%-54 \%$ for NAAT. At $20 \%$ CDI prevalence, the PPVs increased to $81 \%-83 \%$ for GDH EIA, $83 \%-88 \%$ for toxin EIA, and $84 \%-85 \%$ for NAAT. Several local and international guidelines recommend the algorithmic diagnosis of CDI to improve the PPVs and negative predictive values (NPVs), such as two-step algorithms with NAAT or GDH EIA followed by toxin A/B EIA or an alternative algorithm with initial screening for both the GDH (or NAAT) and toxin A/B EIA $[16,23,30]$. Multistep algorithms based on NAAT showed higher values for PPV (approximately 98.5\%) and NPV (approximately 99.0\%) of algorithmic diagnosis followed by toxin A/B EIA compared to a standalone NAAT result (PPV: $45.7 \%$ and NPV: $99.8 \%$ ) [30]. However, delays in obtaining final results may negatively affect patient outcomes. In the alternative algorithm, the use of a single test combining the GDH and toxin $A / B$ assay enables laboratories to complete the diagnosis on the same day [28,31].

Here, we compared the performance of an alternative algorithmic approach using GDH and toxin A/B EIA (QCC and VIDAS) followed by an Xpert assay to that of an Xpert assay alone (one-step approach). In this study, the agreement between the two immunoassay systems (QCC and VIDAS) was almost perfect (kappa values above 0.9). The main differences between these two assays are related to their ability to perform multiple testing and the need for analytical equipment. The QCC assay is an LFIA kit, which is measured using the naked eye and detects $\mathrm{GDH}$ and toxin A/B using one cartridge at a time. The VIDAS GDH and CDAB assay requires additional spaces for semi-automated benchtop laboratory equipment (MINI VIDAS or VIDAS 3, bioMérieux) and can detect GDH and CDAB simultaneously in separate cassettes. When considering the feasibility of use in clinical laboratories, the QCC assay can be used in a small laboratory with little space and few samples. In comparison, the VIDAS assay can give objective results using semi-automatic devices, which can also be used for different assays. The choice between using the QCC or VIDAS assays for CDI diagnosis depends on laboratory conditions such as space, need for a device that can perform different assays, number of tests requested per day, and number of technicians.

Next, we compared the performance of two diagnostic algorithms, where either the QCC or VIDAS GDH and toxin $A / B$ assay is used as the initial screening tool, followed by the Xpert assay. The two-step algorithms using the QCC plus Xpert and the VIDAS plus Xpert assays performed comparably better than using the Xpert alone for the diagnosis of CDI, with an almost perfect agreement (kappa $=0.956$ for both QCC and VIDAS assays) (Table 2). The average cost per sample for the two-step algorithms ( $\$ 15.20$ using the QCC assay and $\$ 18.10$ using the VIDAS assay) is approximately one-third of the cost for the onestep method using only the Xpert assay (\$47). In our institution, the actual average TAT per sample for the twostep algorithms was just 7.6-8.7 minutes more compared to each of the first step methods (QCC and VIDAS). The TAT of the two-step algorithm using the QCC assay (47.6 minutes) was similar to the one-step method using the Xpert assay (50 minutes) in our institution (Table 3). The most appropriate test method should be selected by the individual laboratory, depending on the number of tests performed each day, the amount of laboratory space for equipment, and the number of technicians performing the tests. In addition, the costs and TAT could affect the choice of testing method, as well as whether the onestep method using NAAT alone or a two-step algorithm is utilized.

The limitations of this study include the fact that all specimens were collected from one hospital. The utility and cost-effectiveness of the proposed workflow should be validated by more hospitals with different institutional and laboratory conditions. Additionally, this study did not use currently accepted reference methods (TC or CCNA) and instead used a commercial NAAT (Xpert). Although NAATs are not accepted reference standards, the American Society of Microbiology recommends this method as the best practice for detecting the $C$. difficile toxin gene [16] as the widely-used Xpert assay demonstrated good sensitivity and specificity, comparable to CCNA or TC $[10,24,32]$. Therefore, the use of the Xpert assay as a reference method in this study should not have affected 
our findings. Furthermore, in this study, the equivocal results from the VIDAS CDAB assays were regarded as negative results, which may have influenced the sensitivity and specificity values. There were 17 equivocal results from the VIDAS CDAB assays, and 11 of them had a negative result using the VIDAS GDH and Xpert assays. Six samples with equivocal results from the VIDAS CDAB assay showed positive results using the VIDAS GDH assay, and four of them were positive using the Xpert assay. In our two-step algorithmic approach, if a VIDAS GDHpositive/VIDAS CDAB-equivocal sample is classified as a discordant result, and is followed by the Xpert assay, it will be properly diagnosed via Xpert assay confirmation.

In summary, the QCC and VIDAS assays are both use- ful for the simultaneous detection of GDH and toxin $\mathrm{A} / \mathrm{B}$ as an initial screening method within the two-step algorithm for diagnosing CDI, with comparable sensitivity and specificity. In terms of TAT and cost, the QCC assay is a better choice for small batches of samples, while the VIDAS assay is better for laboratories with medium-to-high throughput sample processing needs.

\section{CONFLICT OF INTEREST}

Abbott Rapid Diagnostics Korea Inc. (Seongnam, Korea) funded and provided the reagents used in this study. However, the company played no role in the interpretation of data and writing of the report.

\section{REFERENCES}

1. Tedesco FJ, Stanley RJ, Alpers DH. Diagnostic features of clindamycin-associated pseudomembranous colitis. N Engl J Med 1974;290:841-3.

2. Bartlett JG. Narrative review: the new epidemic of Clostridium difficile-associated enteric disease. Ann Intern Med 2006;145:758-64.

3. Cohen SH, Gerding DN, Johnson S, Kelly CP, Loo VG, McDonald LC, et al. Clinical practice guidelines for Clostridium difficile infection in adults: 2010 update by the Society for Healthcare Epidemiology of America (SHEA) and the Infectious Diseases Society of America (IDSA). Infect Control Hosp Epidemiol 2010;31:431-55.

4. Gilca R, Hubert B, Fortin E, Gaulin C, Dionne M. Epidemiological patterns and hospital characteristics associated with increased incidence of Clostridium difficile infection in Quebec, Canada, 1998-2006. Infect Control Hosp Epidemiol 2010;31:939-47.

5. Lee YJ, Choi MG, Lim CH, Jung WR, Cho HS, Sung HY, et al. Change of Clostridium difficile colitis during recent 10 years in Korea. Korean J Gastroenterol 2010;55:169-74.

6. Lee JH, Lee SY, Kim YS, Park SW, Park SW, Jo SY, et al. The incidence and clinical features of Clostridium difficile infection; single center study. Korean J Gastroenterol 2010;55:175-82.

7. Kim J, Pai H, Seo MR, Kang JO. Epidemiology and clinical characteristics of Clostridium difficile infection in a Korean tertiary hospital. J Korean Med Sci 2011;26:1258-64.

8. Planche T, Wilcox M. Reference assays for Clostridium difficile infection: one or two gold standards? J Clin Pathol 2011;64:1-5.

9. Brecher SM, Novak-Weekley SM, Nagy E. Laboratory diagnosis of Clostridium difficile infections: there is light at the end of the colon. Clin Infect Dis 2013;57:1175-81.

10. Shin BM, Yoo SM, Shin WC. Evaluation of Xpert C. difficile, BD MAX Cdiff, IMDx C. difficile for Abbott m2000, and Illumigene $\mathrm{C}$. difficile assays for direct detection of toxigenic Clostridium difficile in stool specimens. Ann Lab Med 2016;36:131-7.

11. Juretschko S, Manji R, Khare R, Das S, Dunbar S. Performance evaluation of the Luminex Aries C. difficile assay in comparison to two other molecular assays within a multihospital health care center. J Clin Microbiol 2019;57:e01092- 
19.

12. Swindells J, Brenwald N, Reading N, Oppenheim B. Evaluation of diagnostic tests for Clostridium difficile infection. J Clin Microbiol 2010;48:606-8.

13. Bruins MJ, Verbeek E, Wallinga JA, Bruijnesteijn van Coppenraet LE, Kuijper EJ, Bloembergen P. Evaluation of three enzyme immunoassays and a loop-mediated isothermal amplification test for the laboratory diagnosis of Clostridium difficile infection. Eur J Clin Microbiol Infect Dis 2012;31:3035-9.

14. Ticehurst JR, Aird DZ, Dam LM, Borek AP, Hargrove JT, Carroll KC. Effective detection of toxigenic Clostridium difficile by a two-step algorithm including tests for antigen and cytotoxin. J Clin Microbiol 2006;44:1145-9.

15. Debast SB, Bauer MP, Kuijper EJ; European Society of Clinical Microbiology and Infectious Diseases. European Society of Clinical Microbiology and Infectious Diseases: update of the treatment guidance document for Clostridium difficile infection. Clin Microbiol Infect 2014;20 Suppl 2:1-26.

16. MCDonald LC, Gerding DN, Johnson S, Bakken JS, Carroll KC, Coffin SE, et al. Clinical practice guidelines for Clostridium difficile infection in adults and children: 2017 update by the Infectious Diseases Society of America (IDSA) and Society for Healthcare Epidemiology of America (SHEA). Clin Infect Dis 2018;66:987-94.

17. Surawicz CM, Brandt LJ, Binion DG, Ananthakrishnan AN, Curry SR, Gilligan PH, et al. Guidelines for diagnosis, treatment, and prevention of Clostridium difficile infections. Am J Gastroenterol 2013;108:478-99.

18. Chung HS, Park JS, Shin BM. Laboratory diagnosis of Clostridium difficile infection in Korea: the first national survey. Ann Lab Med 2019;39:317-21.

19. Kim H, Kim WH, Kim M, Jeong SH, Lee K. Evaluation of a rapid membrane enzyme immunoassay for the simultaneous detection of glutamate dehydrogenase and toxin for the diagnosis of Clostridium difficile infection. Ann Lab Med 2014;34:235-9.

20. Yoo IY, Song DJ, Huh HJ, Lee NY. Simultaneous detection of Clostridioides difficile glutamate dehydrogenase and toxin A/B: comparison of the C. DIFF QUIK CHEK COMPLETE and RIDASCREEN assays. Ann Lab Med 2019;39:214-7.

21. Moon HW, Kim HN, Hur M, Shim HS, Kim H, Yun YM. Comparison of diagnostic algorithms for detecting toxigenic Clostridium difficile in routine practice at a tertiary referral hospital in Korea. PLoS One 2016;11:e0161139.

22. McHugh ML. Interrater reliability: the kappa statistic. Biochem Med (Zagreb) 2012;22:276-82.

23. Shin BM. Diagnostic standard guidelines for Clostridium difficile infection in Korea. http://prism.go.kr/homepage/ theme/retrieveThemeDetail.do?research_id=1351000-201800002 (Accessed July 1, 2020).

24. Kraft CS, Parrott JS, Cornish NE, Rubinstein ML, Weissfeld AS, McNult P, et al. A laboratory medicine best practices systematic review and meta-analysis of nucleic acid amplification tests (NAATs) and algorithms including NAATs for the diagnosis of Clostridioides (Clostridium) difficile in adults. Clin Microbiol Rev 2019;32:e00032-18.

25. Carroll KC, Mizusawa M. Laboratory tests for the diagnosis of Clostridium difficile. Clin Colon Rectal Surg 2020;33:7381.

26. Gould CV, Edwards JR, Cohen J, Bamberg WM, Clark LA, Farley MM, et al. Effect of nucleic acid amplification testing on population-based incidence rates of Clostridium difficile infection. Clin Infect Dis 2013;57:1304-7.

27. Longtin Y, Trottier S, Brochu G, Paquet-Bolduc B, Garenc C, Loungnarath V, et al. Impact of the type of diagnostic assay on Clostridium difficile infection and complication rates in a mandatory reporting program. Clin Infect Dis 2013;56:67-73.

28. Planche TD, Davies KA, Coen PG, Finney JM, Monahan IM, Morris KA, et al. Differences in outcome according to Clostridium difficile testing method: a prospective multicentre diagnostic validation study of $\mathrm{C}$ difficile infection. Lancet Infect Dis 2013;13:936-45.

29. Polage CR, Gyorke CE, Kennedy MA, Leslie JL, Chin DL, Wang S, et al. Overdiagnosis of Clostridium difficile infection 
in the molecular test era. JAMA Intern Med 2015;175:1792-801.

30. Crobach MJ, Planche T, Eckert C, Barbut F, Terveer EM, Dekkers OM, et al. European Society of Clinical Microbiology and Infectious Diseases: update of the diagnostic guidance document for Clostridium difficile infection. Clin Microbiol Infect 2016;22 Suppl 4:S63-81.

31. Barbut F, Surgers L, Eckert C, Visseaux B, Cuingnet M, Mesquita C, et al. Does a rapid diagnosis of Clostridium difficile infection impact on quality of patient management? Clin Microbiol Infect 2014;20:136-44.

32. Bai Y, Sun X, Jin Y, Wang Y, Li J. Accuracy of Xpert Clostridium difficile assay for the diagnosis of Clostridium difficile infection: a meta analysis. PLoS One 2017;12:e0185891. 